\title{
Pre-Service Elementary Teachers' Knowledge of Students: The Case of Subtraction
}

\author{
Sumeyra Dogan Coskun* \\ Received: March 18, 2020; received in revised form: April 4, 2020; \\ accepted: April 6, 2020
}

\begin{abstract}
:
Introduction: Although there is ambiguity about the elements of teacher knowledge, all researchers accept that being able to anticipate what errors can be made, the reasons for and the strategies to overcome these errors, in short, the knowledge of students is important for student achievement. In this study, knowledge of students refers to being aware of students' possible errors and underlying reasons for these errors and knowing how to overcome these errors. Based on this consideration, the purpose of this study is to investigate pre-service elementary teachers' knowledge of students on the subtraction topic.
\end{abstract}

Methods: Considering the purpose, the data were collected from 118 preservice elementary teachers who were enrolled in a four-year Elementary Teacher Education program via a task-based questionnaire related to the topic of subtraction and semi-structured interviews following the questionnaire. The task-based questionnaire included three completed incorrect subtraction tasks and was prepared considering the related literature and the elementary school mathematics curriculum of Turkey. Each task in the questionnaire contained a different type of error. The preservice elementary teachers' answers to the task-based questionnaire were categorized as correct, partially correct, wrong, or no answer by means of categorical analysis. The pre-service elementary teachers who gave correct and partially correct answers to the tasks were asked to participate in the second part of the study to learn their possible strategies to overcome the errors made in the tasks.

Results: As a result of the quantitative and qualitative analysis of the preservice elementary teachers' responses, it was found that their knowledge of students for subtraction is limited. Specifically, although the pre-service elementary teachers were partially able to identify the errors in the first and second task, they were not able to identify the error in the third task. Furthermore, they were better able to determine a more commonly occurring subtraction error compared to the uncommon ones. The preservice elementary teachers could not identify the underlying reasons that led the students to the errors. They could not explain what conceptual

\footnotetext{
* Sumeyra Dogan Coskun, Eskisehir Osmangazi University, Department of Elementary and Early Childhood Education, Eskisehir, Turkey; s-dogan@ogu.edu.tr
} 


\title{
Acta Educationis Generalis \\ Volume 10, 2020, Issue 3
}

\begin{abstract}
knowledge related to the topic of subtraction the student lacked that resulted in the errors. As the pre-service teachers did not attain these reasons, they were not able to provide strategies to overcome these errors different than restating the rules or procedures to overcome students' errors.
\end{abstract}

Discussion: Only being able to identify the errors is not enough to make the instruction effective. Teachers also need to know and provide a rationale for why the errors happen and how to overcome them (Even \& Tirosh, 1995). Contrary to this statement, the pre-service elementary teachers in this study could not attempt to understand the students' thinking or could not explain the reasons behind students' errors with the notion of subtraction. Son (2013) emphasizes that pre-service teachers tend to explain the reasons for students' errors as procedural. Similar to this emphasis, the pre-service teachers identified the errors as resulting from not applying procedures carefully or not enough knowing algorithms to find correct solutions. However, without addressing the reasons or focusing on procedures does not promote students' understanding of the related topic (An, Kulm, \& Wu, 2004). The pre-service teachers' difficulties in identifying the possible conceptual reasons may result from deficits in knowledge of students (Fennema \& Franke, 1992; Ball et al., 2008).

Limitations: The findings were limited with the responses of the preservice elementary teachers participating in this study. Moreover, the preservice elementary teachers' knowledge of students was investigated within the scope of subtraction.

Conclusions: Although the pre-service elementary teachers could identify students' errors on subtraction, they had difficulty in identifying the reasons and suggesting strategies to overcome the errors. Therefore, it can be concluded that the pre-service teachers' knowledge of students for the topic of subtraction is limited. An implication of this is that teacher educators need to include error-analysis tasks to help pre-service teachers be aware of the importance of their knowledge of students.

Key words: error, knowledge of students, pre-service elementary teachers, subtraction.

\section{Introduction}

To emphasize the importance of operations with numbers, the National Research Council [NRC] (2001) states "number is a rich, many-sided domain whose simplest forms are comprehended by very young children and whose far reaches are still being explored by mathematicians. Proficiency with numbers and numerical operations is an important foundation for further education in mathematics and in fields that use mathematics." The National Council of Teachers of Mathematics [NCTM] (2000) also accepts attaining numerical fluency in numerical operations as one of the essential components of 


\section{Acta Educationis Generalis \\ Volume 10, 2020, Issue 3}

elementary mathematics education. In the same way, NRC (2001) lists procedural fluency among strands of mathematical proficiency. What is meant here by procedural fluency is not just performing or emphasizing necessary arithmetic computations. Instead, it refers to computing these calculations with a conceptual understanding (Cobb, 1991). That is, learning to perform algorithms with meaning refers to procedural fluency. It is a fact that teachers' knowledge impacts their teaching practices, hence students' procedural fluency. In this context, this study aims to investigate pre-service elementary teachers' knowledge of students on the subtraction topic.

\section{Teacher knowledge}

Since teacher knowledge is accepted as one of the characteristics of an effective teacher and an effective teacher may have the greatest influence on students' success in mathematics, there have been a number of studies related to it (Fennema \& Franke, 1992). That is, to improve mathematics instruction, and hence to improve students' learning, a better understanding of teacher knowledge and its development is important (Ball, Thames, \& Phelps, 2008). However, there are many different ideas as to what knowledge and skills constitute teacher knowledge. Shulman (1986) mentions that teachers need to have three categories of knowledge which are content knowledge, pedagogical content knowledge, and curricular knowledge. The first one, content knowledge, is defined as "the amount and organization of knowledge per se in the mind of the teacher." (Shulman, 1986, p. 9) Although content knowledge is important as it includes basic facts of a subject, how these facts are related to each other, and how they are verified, it is not enough to teach the subject. At this point, pedagogical content knowledge which is directly related to a teacher's ability to represent content in a way that students can easily understand the content is required. Specifically, Shulman (1986) defines pedagogical content knowledge as "the ways of representing and formulating the subject that makes it comprehensible to others." The last one, curricular knowledge refers to how the content plays out throughout the curriculum.

\subsection{Mathematical knowledge for teaching}

Since Shulman's framework was not specific for one subject, several studies have used his model and proposed their own models (Ball et al., 2008; Fennema \& Franke, 1992; Grossman, 1990). One of these researchers, Ball and her colleagues (2008) identified the essential elements of knowledge to teach mathematics and designed a new model for mathematics teaching by extending Shulman's framework. They used a new term, Mathematical Knowledge for Teaching (MKT), which was defined as "the mathematical knowledge needed to carry out the work of teaching mathematics." (Ball et al., 2008, p. 395) As can be easily seen in Figure 1, subject matter knowledge and pedagogical content knowledge are two main domains of the MKT model. 


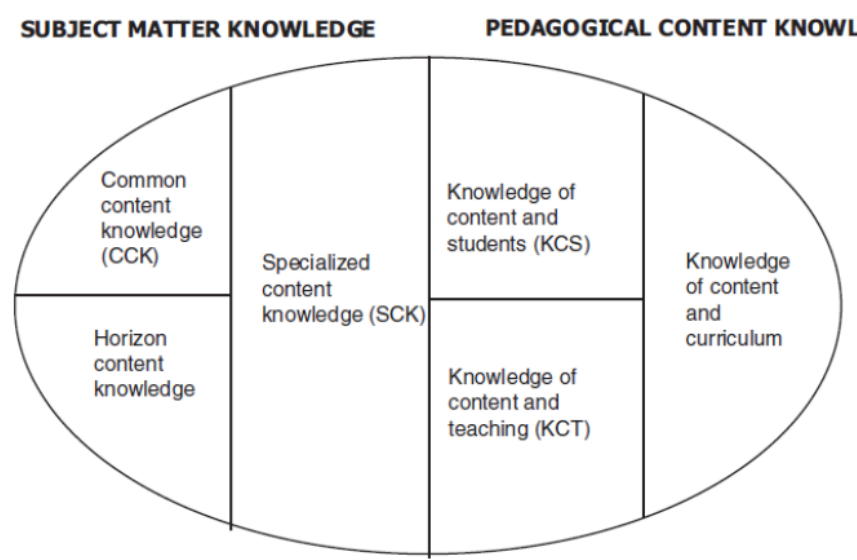

Figure 1. Model of mathematical knowledge for teaching (Ball et al., 2008, p. 403).

According to their model, subject matter knowledge includes common content knowledge, specialized content knowledge, and horizon content knowledge. The first sub-domain of the subject matter knowledge, common content knowledge, is the knowledge of any well-educated person which is not unique to teaching. On the other hand, specialized content knowledge is defined as "mathematical knowledge and skill uniquely needed by teachers in the conduct of their work." (Ball et al., 2008, p. 400) In other words, teachers with specialized content knowledge know how to clearly present ideas, effectively respond to their students' questions, and know which examples help students understand the content. Lastly, a teacher with horizon content knowledge links the content not only with the previous years but also with the following years. Similar to the first domain of MKT, the second domain, pedagogical content knowledge is subdivided into three sub-domains: knowledge of content and teaching, knowledge of content and curriculum, and knowledge of content and students. Knowledge of content and teaching is "knowledge that combines knowledge about mathematics and knowledge about teaching." (Ball, et al., 2008, p. 401) This sub-dimension is related to the selection of tasks and order in which tasks are presented throughout instruction. Furthermore, teachers with this knowledge know both the advantages and disadvantages of models or representations used to solve tasks. The second sub-domain, knowledge of content and curriculum, is the knowledge of how teachers relate mathematics with mathematics curriculum. The last sub-domain, knowledge of content and students includes both knowledge of specific content and knowledge of students' thinking and learning process. That is, teachers with this knowledge are aware of students' understanding, conceptions, and errors for specific content (Ball, et al., 2008). 


\subsection{Rationale and purpose of the study}

When the above-mentioned and the other models for teacher knowledge are examined in detail, despite the slight differences among them, it can be easily seen that most of them emphasize the knowledge of students and their learning (Ball et al., 2008; Grossman, 1990, Shulman, 1986). One of those aspects that affect students' learning is their errors. One of the topics in which students make errors is subtraction. Students commit errors in subtraction as they cannot apply the borrow operation (Imbo \& LeFevre, 2010). Since they have difficulties in borrowing, they prefer to subtract the smaller number from the bigger one regardless of their places (NRC, 2002; Riccomini, 2005). The borrowing error is especially observed when one of the digits of the subtrahend is zero (Ashlock, 2002). Specifically, since students think that they cannot subtract a number from zero, they just write zero as a result. Contrary to students' errors and difficulties in subtraction, the topic of subtraction is one of the fundamental concepts of mathematics and the significance of the topic can be clearly seen throughout the elementary mathematics curriculum (Ministry of National Education, 2018; NCTM, 2000). Therefore, if teachers do not know how to teach subtraction both procedurally and conceptually to overcome students' errors and misconceptions, then students may fail to reach a higher level of mathematics.

In order to be able to help students gain a conceptual understanding of subtraction, teachers need to have knowledge of content and students. Contrarily, most of the pre-service elementary teachers think that if they teach mathematics directly by providing rules and algorithms, students would reapply them and be successful in mathematics. Hence, they just focus on their students' numerical answers by exploring whether they are right or wrong. However, NCTM (2000) emphasizes that teachers need to use their students' answers as an opportunity to enhance students' learning rather than to provide a superficial right or wrong reply. Therefore, teachers need to provide opportunities for their students to explain their answers and thoughts, and ask questions related to their answers (Lukášová \& Pavelková, 2017; Trávníčková, 2018). Otherwise, they may not be able to identify the points that need to be re-addressed or make invalid conclusions regarding their students' understanding. Contrary to this emphasis, they do not question or look for underlying reasons for their students' wrong answers and do not know how to overcome these errors (Crespo, 2000; Tirosh, 2000). Furthermore, some of them even tend to hide their students' errors (Son \& Sinclair, 2010). Then, the first natural question that comes to mind will be how teaching can be effective without overcoming students' errors. In fact, teachers may use these errors as an instructional source to help students learn the subtraction conceptually by asking students to explain the errors that they made (Curry, 2004; Große \& Renkl, 2007). To state differently, allowing students to explain why their answers are not right, or how they can correct their errors may help them reflect on what they did and why they did and then foster a deeper understanding of the subtraction. Throughout these processes, teachers 


\section{Acta Educationis Generalis \\ Volume 10, 2020, Issue 3}

may try to interpret by identifying the specific features of their students' errors and plan how to deal with them (Larrain \& Kaiser, 2019). However, to be able to succeed in the above-mentioned processes, the first step is teachers' examination of students' answers (Ashlock, 2002).

As mentioned before, although there is ambiguity about the elements of teacher knowledge, all researchers accept that being able to anticipate what errors can be made, the reasons for and the strategies to overcome these errors, in short, the knowledge of students is important for student achievement (Brodie, 2014; Ma, 1999; Peng \& Luo, 2009). In this study, knowledge of students refers to being aware of students' possible errors and underlying reasons for these errors and knowing how to overcome these errors. Based on this consideration, this study aims to examine whether or not pre-service elementary teachers identify and overcome students' errors related to the subtraction. Apart from forcing the participants of this study to think deeply about students' errors not only related to subtraction, but they would also think about other mathematics topics as well.

\section{Methodology}

\subsection{Research design}

Qualitative studies try to understand "the meaning people have constructed: that is, how they make sense of the world and the experiences they have in the world." (Merriam, 1998, p. 6) A case study, one of the types of qualitative studies, is preferred when the researchers try to get a detailed understanding of the related issue (Creswell, 2007). To gain a deeper understanding of the preservice elementary teachers' knowledge of students' errors on the topic of subtraction, a case study design was used. In this study, while senior pre-service elementary teachers are the case, knowledge of students' errors is the unit of analysis of the study.

\subsection{Participants}

The data of this study were collected from pre-service elementary who were enrolled in a four-year Elementary Teacher Education program at a university in Turkey. The pre-service elementary teachers took two content courses focusing on basic facts of mathematics and two teaching courses focusing on instructional methods and strategies for teaching these facts. Since the qualitative case studies do not aim to generalize findings, instead, try to get a deeper understanding of the case, purposive sampling, one of the non-probabilistic sampling methods, was used to select the participants of this study. To see whether or not preservice elementary teachers have enough knowledge to overcome their students' errors related to the subtraction following their graduation, the senior pre-service elementary teachers who had already taken both content and teaching courses were asked to volunteer to participate in this study. There were 118 pre-service 


\section{Acta Educationis Generalis \\ Volume 10, 2020, Issue 3}

elementary teachers who accepted to be a volunteer in this study during the fall semester of the 2018-2019 academic year.

\subsection{Data collection}

To get detailed information related to pre-service elementary teachers' knowledge of students' errors on the subtraction, the data were collected via a task-based questionnaire related to the topic of subtraction and semi-structured interviews following the questionnaire. The task-based questionnaire including three completed incorrect subtraction tasks was prepared by the author of this study considering the related literature and the elementary school mathematics curriculum of Turkey. Incorrect tasks in the worksheet were representative of errors made by elementary school students for the topic of subtraction. To determine the content validity of the questionnaire, the prepared tasks were controlled by a mathematics educator and an elementary school teacher.

Since this study tries to investigate pre-service elementary teachers' knowledge of students' errors, pre-service teachers were asked to explain students' solutions and errors on each task in detail. Furthermore, each task contained a different type of error. For example, there were two types of errors in the first task. The first one was a very common type of error, was called "smaller from larger error (SFLE)." (Ashlock, 2002) If a student subtracted a smaller digit from a bigger digit in the same column regardless of which is on top, then it was called SFLE (e.g. 52-37=25, with the SFL error 7-2=5). The second error in this task was related to borrowing a ten, which was called "forgetting to decrease the value (FDV)." That is, if a student could not subtract the numbers in the ones place, he had to borrow a ten from tens place. However, the student forgot to decrease value of the digit by one in the tens column (e.g. 52-37=25, with the FDV error $12-7=5$ and $5-3=2)$. There were also two types of errors which were called "borrowing tens error (BTE)" and "arithmetic error (AE)" in the second task. If a student borrowed a ten from tens place and forgot to add this ten to digit in the ones place, then it was called BTE (e.g., 81-52=28, with the BTE 10-2=8). If a student borrowed a ten from tens place, added this ten to digit in the ones place; however, the student made an arithmetic error in the subtraction, then it was called as $\mathrm{AE}$ (e.g. 81-52=28, with the $\mathrm{AE} 11-2=8$ ). The final error in the third task was called "no need to borrow (NNTB)." Although there was no need to borrow a ten from tens place, the student borrowed a ten and added this ten to the digit in the ones place. By the way, he also decreased the value of the digit by one in the tens place of the minuend. Then he subtracted the digit in the ones place of subtrahend from the digit in the ones place of minuend and carried the ten into the tens place of subtrahend (e.g. 95-32=43, with the NNTB $15-2=13$ and $85-42=43$ ). The subtraction tasks and errors of the students in each task are given in Table 1. 


\section{Acta Educationis Generalis \\ Volume 10, 2020, Issue 3}

Table 1

Subtraction tasks in the task-based questionnaire and classification of errors

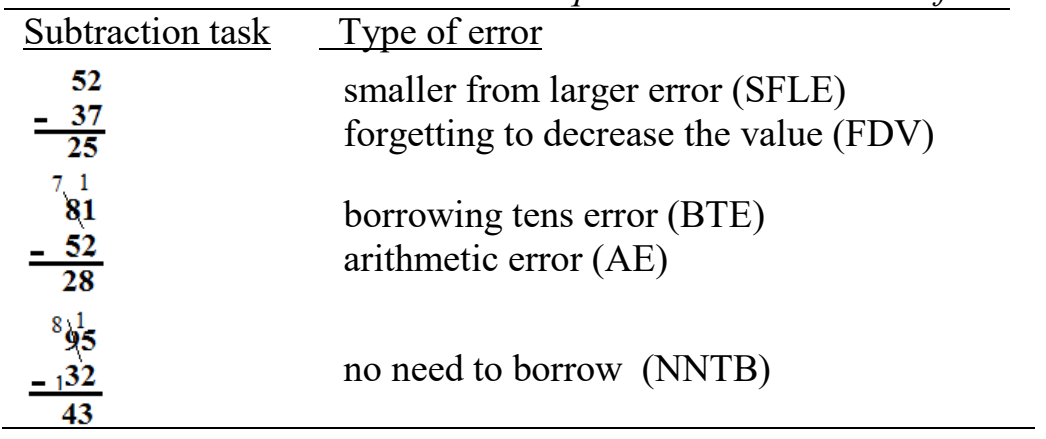

To understand the pre-service elementary teachers' thoughts and to get a complete picture of their knowledge of students' errors related to the subtraction, semi-structured interviews were also conducted with 25 of the senior pre-service elementary teachers. Most of the interview questions were related to the preservice elementary teachers' previous answers given to the tasks in the taskbased questionnaire. Specifically, if the pre-service elementary teachers were able to correctly identify the errors in the tasks, then they were asked the reasons for these errors and strategies that can be used to overcome these errors.

\subsection{Data analysis}

The first stage of the data analysis process was examining the pre-service elementary teachers' answers to the task-based questionnaire. Their answers were categorized as correct, partially correct, wrong, or no answer by means of categorical analysis. Specifically, if the pre-service elementary teachers identified the errors and explained them in detail using the correct terminology, their answers were coded as correct. On the other hand, if the pre-service elementary teachers could not use the correct terminology and their answers lacked enough explanation, then their answers were coded as partially correct. When they could not identify the errors correctly, their answers were coded as incorrect and as blank for they could not give an answer.

Then, the pre-service elementary teachers who gave correct and partially correct answers to the tasks were asked to participate in the second part of the study to learn their possible strategies to overcome the errors made in the tasks. The semi-structured interview questions were prepared for each of the pre-service elementary teachers who were the volunteers to conduct interviews. That is, the questions asked throughout the interviews could be different from one another. The pre-service elementary teachers' answers were scored both by the researcher and a graduate student for the reliability of the scores. The researcher and the 


\section{Acta Educationis Generalis \\ Volume 10, 2020, Issue 3}

graduate student scored randomly selected $50 \%$ of pre-service elementary teachers' answers independently and calculated the inter-scorer reliability.

\section{Findings}

The findings of this study were presented in three sections considering the tasks given in the task-based questionnaire, namely, the identification of the errors for the first task, the identification of the errors for the second task, and the identification of the errors for the third task, respectively.

\subsection{The identification of the errors for the first task}

From Table 2, the analysis of the pre-service elementary teachers' answers shows that most teachers identified an SFL error as the only error while four of the teachers determined there were both SFL and FDV errors.

Table 2

Frequency (and percentage) of pre-service elementary teachers' answers for the first task

\begin{tabular}{lcccc}
\hline Subtraction task & $\frac{\text { Correct }}{f}$ & $\frac{\text { Partially correct }}{f}$ & $\frac{\text { Wrong }}{f}$ & $\frac{\text { No answer }}{f}$ \\
$\mathbf{5 2}$ & & $111(94 \%)$ & $2(2 \%)$ & $1(1 \%)$ \\
$\mathbf{- 3 7}$ & $4(3 \%)$ & & & \\
\hline $\mathbf{2 5}$ & & &
\end{tabular}

When the pre-service elementary teachers who identified both types of errors made in the first task were interviewed, it was seen that they could not use the correct terminology while explaining these errors. For example, one of these teachers stated that:

The student knows that s/he cannot subtract 7 from 2. So s/he is taking a 10 in the tens place and adds it to 2 in the one's place. Now s/he subtracts 7 from 12 which equals 5 . However, s/he forgets that 5 becomes 4 . So s/he subtracts 3 from 5 and finds 2 which is wrong.

Although the pre-service elementary teachers listed different reasons for the errors made in the first task without explaining them deeply enough, most of their explanations related to the SFL error. Furthermore, one of the pre-service elementary teachers mentioned that she does not know the exact reason for the SFL error; however, it may result from teachers' explanations. Specifically, she stated that:

Most of the time teachers say that you cannot subtract a big number from a small number. So the student may think that s/he can subtract the small number from the big number irrespective of their place. That is, the student may subtract 2 from 7 and find 5 which is again wrong.

Similarly, another pre-service elementary teacher mentioned that: 


\section{Acta Educationis Generalis \\ Volume 10, 2020, Issue 3}

Teachers in elementary schools always say that we have to check whether or not the big number is on top. If the number on top is bigger than the bottom, then we can find the difference. Otherwise, we cannot subtract the numbers.

When examining the pre-service elementary teachers' strategies to overcome the errors made in the first task, none of them focused on the students' errors. Instead, they mentioned that their strategy would be to give similar subtraction tasks to the students several times and to expect that the students will subtract correctly. An excerpt from one of the pre-service elementary teachers' interview was given below:

Actually, students know that they cannot subtract bigger numbers from smaller numbers; however, since some of them have a partial understanding of the subtraction, they make similar errors. Thus, I need to make sure to review the subtraction rules and make students practice subtraction problems.

Considering the pre-service elementary teachers' answers for the first task, it can be concluded that their explanations about the reasons for students' errors and possible strategies to handle these errors were not much different from each other. Rather than mentioning possible reasons related to students' thinking as well, nearly all of the pre-service elementary teachers accepted teachers' explanations as a possible reason for students' errors. As evidenced by preservice elementary teachers' statements, their strategies were not focused on conceptual understanding, rather they were procedure-oriented. Due to the lack of their pedagogical explanations, it can be concluded that their knowledge of students' errors for the first task is somewhat limited.

\subsection{The identification of the errors for the second task}

Similar to the first task, both error types which were BTE and AE in the second task were determined by only 4 out of 118 pre-service elementary teachers. Furthermore, 20 of these elementary teachers could not find the error.

Table 3

Frequency (and percentage) of pre-service elementary teachers' answers for the second task

\begin{tabular}{lcccc}
\hline Subtraction task & $\frac{\text { Correct }}{f}$ & $\frac{\text { Partially correct }}{f}$ & $\frac{\text { Wrong }}{f}$ & $\frac{\text { No answer }}{f}$ \\
$\mathbf{7 1}$ & & & & \\
$\mathbf{8 1}$ & $4(3 \%)$ & $94(80 \%)$ & $14(12 \%)$ & $6(5 \%)$ \\
$\mathbf{- 5 2}$ & & & &
\end{tabular}

Even among those 94 pre-service elementary teachers who identified one of these errors, only 10 of them determined the BTE error, showing a lack of 


\section{Acta Educationis Generalis \\ Volume 10, 2020, Issue 3}

knowledge considering the students' errors related to the subtraction. For the BTE, one pre-service elementary teacher mentioned that:

The student knows that he cannot take 2 from 1. So s/he is taking a 10 in the tens place; however, s/he forgets to add this ten to digit 1 in the ones place. That is, the student subtracts 2 directly from 10 and gets 8 .

For the AE, the pre-service elementary teachers think that the student knows to borrow and add this 10 to the digit in the ones place, 1 in this task. According to them, the only error is an arithmetic error which means that the student made this error by a fault. That is, the pre-service elementary teachers did not attribute the error to forgetting to add 10 to the digit in the ones place. Since these teachers think that this fault might rarely occur, they claim that asking students to check if they subtracted correctly would be an effective strategy to overcome this error. When they were asked to mention other strategies to address the error, they could not come up with anything.

Apart from the explanations given above, what was interesting but not necessarily correct was that some of the pre-service elementary teachers provided their explanations for the error made in the second task. Some of their explanations were given below:

The student does not know subtraction. First, s/he multiplies the digits in the ones place which are 1 and 2 and writes the result (2) in the tens place of the result. Then, s/he multiplies with 8 and 1 and writes the result (8) in the ones place of the result.

The student thinks that subtraction is related to a big and a small number. S/he takes the bigger digit of minuend and writes it in the ones place of the result. Then s/he takes the smaller digit of the subtrahend and writes it in the tens place of the result.

The student borrows 9 instead of 10 and adds 9 to 1 in the ones place of the minuend.

The student borrows 10 and adds this 10 to 1 in the ones place of the minuend. Then the student subtracts 2 from 11 and finds 9 as a difference. However, since the student got a 1 at the beginning, s/he has to subtract this 1 again from 9 which is 8 .

The student knows that he cannot subtract 2 from 1. Although s/he knows that he has to borrow, s/he does not know where he borrows from. He decreases the value of the digit by one in both ones and tens place of minuend.

By considering the pre-service elementary teachers' answers for the second task, this study might mean that although the pre-service elementary teachers were partially able to identify students' errors, they could not provide explanations on how they would overcome these errors. Instead, some of them mentioned that they would re-teach how the subtraction algorithm works. Showing students the algorithms may bring the correct answers for the subtraction problems; however, it does not mean that they would understand the reasons for their errors. Therefore, it can be stated that the pre-service elementary teachers had limited 


\section{Acta Educationis Generalis \\ Volume 10, 2020, Issue 3}

knowledge of students' thinking as their explanations regarding the strategies were limited.

\subsection{The identification of the error for the third task}

When the pre-service elementary teachers' answers for the third task were analyzed, it was seen from Table 4, there were not any correct or partially correct answers. Therefore, it can be said that they had difficulties in determining the student's error in the third task compared to the first and second tasks. In fact, $67 \%$ of them made a wrong explanation for the error and $33 \%$ of them could not give an explanation for it. The frequency and percentage of their answers were presented in Table 4.

\section{Table 4}

Frequency (and percentage) of pre-service elementary teachers' answers for the third task

\begin{tabular}{|c|c|c|c|c|}
\hline$\underline{\text { Subtraction task }}$ & $\frac{\text { Correct }}{f}$ & $\frac{\text { Partially correct }}{f}$ & $\frac{\text { Wrong }}{f}$ & $\frac{\text { No answer }}{f}$ \\
\hline $\begin{array}{r}811 \\
95 \\
-132 \\
43\end{array}$ & $0(0 \%)$ & $0(0 \%)$ & $79(67 \%)$ & $39(33 \%)$ \\
\hline
\end{tabular}

As none of the pre-service elementary teachers identified the error in the third task, some of the wrong explanations were given below:

The student subtracts 2 from 5 in the correct way. Then s/he thinks that s/he has to borrow a ten and add this 10 somewhere. Since s/he subtracted the digits in the ones place, s/he borrows a 1 and adds it to 3 (the digit in the ones place of subtrahend) which equals to 4. Finally, s/he subtracts 4 from 8 and writes the difference as 43.

Although the student subtracts the digits in the ones place accurately, s/he could not subtract the digits in the tens place. S/he may be a bit careless.

The student thinks that s/he has to borrow a ten from a tens place of minuend for both the digit in the ones place of minuend and the digit in the tens place of the subtrahend.

The student subtracts the digits in the ones column. However, when he looks to the digits in the tens column, he thinks that he has to subtract 9 from 3 and he knows that he cannot subtract. So he takes a ten from 9 and adds this 10 to 3 to make 13. Then he subtracts 9 from 13 and gets 4 for the digit in the tens place of the difference.

The student thinks that he has to borrow a ten from a tens place of minuend for both the digits in the ones place of minuend and subtrahend.

Since the pre-service elementary teachers were not able to identify the error in the third task, none of them were interviewed in the second part of the study to 


\section{Acta Educationis Generalis \\ Volume 10, 2020, Issue 3}

find out how they can overcome the error in the third task. Therefore, with respect to the third task, the most outstanding finding was the pre-service elementary teachers' weakness in both identifying and overcoming the error.

\section{Discussion and implications}

This study examined the pre-service elementary teachers' knowledge of students for the topic of subtraction. The findings indicated that although the pre-service elementary teachers were partially able to identify the errors in the first and second task, they were not able to identify the error in the third task. Considering the first and second tasks, they were better able to determine a more commonly occurring subtraction error which was SFL and AE. On the other hand, they had difficulty in determining less common subtraction errors which were FDV and BTE in the first and second tasks, respectively. Therefore, the reason for not being able to identify the error in the third task may result from the type of error as the error in the third task was not a common one. Actually, identifying the most common errors is important as students would possibly make these errors (Resnick, 1982). However, being able to identify the errors is not enough to make the instruction effective. Teachers also need to know and provide a rationale for why errors happen and how to overcome them (Even \& Tirosh, 1995). Contrary to this statement, the pre-service elementary teachers in this study could not attempt to understand the students' thinking or could not explain the reasons behind students' errors with the notion of subtraction. Specifically, they could not explain what conceptual knowledge related to the topic of subtraction the student lacked that resulted in those errors. Son (2013) emphasizes that pre-service teachers tend to explain the reasons for students' errors as procedural. Similar to this emphasis, the pre-service teachers identified the errors as resulting from not applying procedures carefully or not enough knowing algorithms to find correct solutions. However, without addressing the reasons or focusing on procedures does not promote students' understanding of the related topic (An, Kulm, \& Wu, 2004). The pre-service teachers' difficulties in identifying the possible conceptual reasons may result from deficits in their knowledge of students (Fennema \& Franke, 1992; Ball et al., 2008). As the preservice teachers did not attain these reasons, they were not able to provide strategies to overcome these errors. They just suggested presenting the rules, showing how to carry out the subtraction algorithm again, and providing some other tasks. Teachers who lack instructional strategies' knowledge tend to think that restating the rules and having students practice similar tasks would help them overcome students' errors (Fennema \& Franke, 1992; Kinach, 2002). Considering this statement, it can be concluded that the pre-service teachers' knowledge of students for the topic of subtraction is limited. 


\section{Acta Educationis Generalis \\ Volume 10, 2020, Issue 3}

\section{Conclusions}

This study provides practical implications as it shows the important role of teacher educators and teacher education programs. Specifically, Cuban (1993) states that teachers tend to teach in a similar way in which they had been taught. Therefore, to make pre-service elementary teachers familiar with, and help them provide an effective instruction to overcome, mathematics teaching courses in the teacher education programs can be reorganized in a way that they include some information about students' errors. For example, teacher educators can include similar tasks to the ones given in this study and create an environment in which pre-service teachers engage in identifying and providing strategies to deal with errors. Including these tasks would not only allow teachers to learn common student errors, but also allow them to notice the importance of these errors as a source of their students' mathematical thinking. That is, by means of these tasks, pre-service teachers learn how to think about mathematics from a student's perspective in addition to a teacher's perspective. The findings of this study call for future studies examining pre-service elementary teachers' knowledge of students on other topics of mathematics to inform teacher educators.

\section{References}

An, S., Kulm, G., \& Wu, Z. (2004). The pedagogical content knowledge of middle school, mathematics teachers in China and the US. Journal of Mathematics Teacher Education, 7(2), 145-172.

Ashlock, R. B. (2002). Error patterns in computation (8th ed.). New York: Merrill.

Ball, D. L., Thames, M. H., \& Phelps, G. (2008). Content knowledge for teaching: What makes it special? Journal of Teacher Education, 59(5), 389407.

Brodie, K. (2014). Learning about learner errors in professional learning communities. Educational Studies in Mathematics, 85(2), 221-239.

Cobb, P. (1991). Reconstructing elementary school mathematics. Focus on Learning Problems in Mathematics, 13(2), 3-32.

Crespo, S. (2000). Seeing more tan right and wrong answers: Prospective teachers' interpretations of students' mathematical work. Journal of Mathematics Teacher Education, 3(2), 155-181.

Creswell, J. W. (2007). Research Design: Qualitative, Quantitative, and Mixed Methods Approaches (2nd ed.). Thousand Oaks, CA: Sage.

Cuban, L. (1993). How Teachers Taught: Constancy and Change in American Classrooms 1890-1990 (2nd ed.). New York: Teachers College Press.

Curry, L. A. (2004). The effects of self-explanations of correct and incorrect solutions on algebra problem-solving performance. In K. Forbus, D. 


\section{Acta Educationis Generalis \\ Volume 10, 2020, Issue 3}

Gentner, \& T. Regier (Eds.), Proceedings of the Annual Meeting of the Cognitive Science Society, 26(26). Mahwah, NJ: Erlbaum.

Even, R., \& Tirosh, D. (1995). Subject-matter knowledge and knowledge about students as sources of teacher presentations of the subject matter. Educational Studies in Mathematics, 29(1), 1-20.

Fennema, E., \& Franke, M. L. (1992). Teachers' knowledge and its impact. In D. A. Grouws (Ed.), Handbook of Research on Mathematics Teaching and Learning: A Project of the National Council of Teachers of Mathematics (pp. 147-164). New York, NY, England: Macmillan Publishing Co, Inc.

Fuson, K. C. (1992). Research on whole number, addition and subtraction. In D. A. Grouws (Ed.), Handbook of Research on Mathematics Teaching and Learning (pp. 243-295). New York: Macmillan Library reference Simon \& Schuster Macmillan.

Große, C. S., \& Renkl, A. (2007). Finding and fixing errors in worked examples: Can this foster learning outcomes? Learning and Instruction, 17(6), 612634.

Grossman, P. L. (1990). The Making of a Teacher: Teacher Knowledge and Teacher Education. New York: Teachers College Press, Columbia University.

Imbo, I., \& LeFevre, J. A. (2010). The role of phonological and visual working memory in complex arithmetic for Chinese- and Canadian-educated adults. Memory \& Cognition, 38(2), 176-185.

Kinach, B. M. (2002). A cognitive strategy for developing pedagogical knowledge in the secondary mathematics methods course: Toward a model of effective practice. Teaching and Teacher Education, 18(1), 51-71.

Larrain, M., \& Kaiser, G. (2019). Analysis of students' mathematical errors as a means to promote future primary school teachers' diagnostic competence. Uni-Pluri/Versidad, 19(2), 17-39.

Lukášová, H., \& Pavelková, M. (2017). Pupils’ Questions in Dialogic Teaching from the Perspective of Pedagogical Research. Acta Educationis Generalis, 7(3), 76-87. https://doi.org/10.1515/atd-2017-0025

Ma, L. (1999). Knowing and Teaching Elementary Mathematics: Teachers' Understanding of Fundamental Mathematics in China and the United States. Mahwah, NJ: Lawrence Erlbaum Associates.

Merriam, S. B. (1998). Qualitative Research and Case Study Applications in Education. San Francisco: Jossey-Bass.

Ministry of National Education [MoNE]. (2018). Mathematics Program for Elementary and Middle School. Ankara: Devlet Kitapları Müdürlügüü.

National Council of Teachers of Mathematics. (2000). Principles and Standards for School Mathematics. Reston, Virginia: National Council of Teachers of Mathematics. 
National Research Council. (2001). Adding It Up: Helping Children Learn Mathematics. Washington, DC: National Academy Press.

Peng, A., \& Luo, Z. (2009). A framework for examining mathematics teacher knowledge as used in error analysis. For the Learning of Mathematics, 29(3), 22-25.

Resnick, L. B. (1982). Syntax and semantics in learning to subtract. In T. P. Carpenter, J. M. Moser, \& T. A. Romberg (Eds.), Addition and Subtraction: A Cognitive Perspective (pp. 136-155). Hillsdale: Erlbaum.

Riccomini, P. J. (2005). Identification and remediation of systematic error patterns in subtraction. Learning Disability Quarterly, 28(3), 233-242.

Shulman, L. S. (1986). Those who understand: Knowledge growth in teaching. Educational Researcher, 15(2), 4-14.

Son, J. W. (2013). How pre-service teachers interpret and respond to student errors: Ratio and proportion in similar rectangles. Educational Studies in Mathematics, 84(1), 49-70.

Son, J. W., \& Sinclair, N. (2010). How pre-service teachers interpret and respond to student geometric errors. School Science and Mathematics, 110(1), 31-46.

Tirosh, D. (2000). Enhancing prospective teachers' knowledge of children's conceptions: The case of division of fractions. Journal for Research in Mathematics Education, 31(1), 5-25.

Trávníčková, P. (2018). An analysis of teacher's didactical activity in the context of children's preconception usage. Acta Educationis Generalis, 8(2), 40-53. https://doi.org/10.2478/atd-2018-0010

Young, R. M., \& O'Shea, T. (1981). Errors in children's subtraction. Cognitive Science, 5(2), 153-177. 